\title{
Pengaruh Pendapatan Asli Daerah dan Dana Perimbangan terhadap Pertumbuhan Ekonomi Provinsi Sumatera Selatan 2014-2018
}

\author{
Endang Kusdiah Ningsih, Dwi Eka Noviaty \\ Fakultas Ekonomi Universitas IBA \\ Correspondence email: endanghasan62@gmail.com
}

\begin{abstract}
The purpose of this study is to prove empirically the effect of Regional Own-Source Revenue and Balanced Funds to economics growth in province of South Sumatera. The data used is secondary data during 2014-2018 from Central Statatistics Agency (BPS) and Report of Economics and Finance (KEK). Methods of data analysis in this study is to use multiple linear regression analysis. The result showed that of Regional Own-Source Revenue and Balanced Funds has significant effect to economics growth simultaneously. As partialy, Regional Own-Source Revenue has significant effect to economics groth, and Balanced Funds has not significant effect to economics growth.
\end{abstract}

Keywords : Regional Own-Source Revenue; Balanced Funds; economics growth

\section{PENDAHULUAN}

Otonomi daerah yang sudah berjalan selama dua dasawarsa merupakan implementasi dari UU No.22 tahun 1999 tentang Pemerintahan Daerah dan UU No,25 tahun 1999 tentang Perimbangan Keuangan antara Pemerintah Pusat dan daerah. Kedua undag-undang ini disempurnakan dengan UU no.32 tahun 2004 dan UU No. 33 tahun 2004. Otonomi daerah dimaksudkan sebagai kewenangan daerah untuk mengatur dan mengurus keoentingan masyarakat setempat menurut porakarsa sendiri berdasarkan aspirasi masyarakat. Penyelenggaran desentralisasi ini tentu saja memerlukan sumber pendanaan yang besar.Sesuai dengan pasal 5 UU No.33 tahun 2004, sumber pendapatan daerah dalam rangka pelaksanaan desentralisasi terdiri dari Pendapatan Asli Daereah (PAD, Dana Perimbangan dan Lain-lain Pendapatan Yang Sah. Pendapatan Asli Daerah (PAD) merupakan cerminan kemandirian suatu daerah dalam memenuhi kebutuhan dan mensejahterahkan masyarakat daerahnya. PAD diperoleh dari pemanfaatan dan pengelolaan sumber daya yang telah dimiliki daerah tersebut. Dalam kaitannya dengan pelaksanaan otonomi daerah, peningkatan PAD selalu diupayakan karena merupakan penerimaan dalam usaha untuk membiayai penyelenggaraan pemerintah daerah.

Dana Perimbangan adalah dana yang bersumber dari.pendapatan APBN yang dialokasikan kepada daerah untuk mendanai kebutuhan daerah dan juga bertujuan untuk mengurang ketimpangan sumber pendanaan pemerintahan antara pusat dan daerah serta untuk mengurangi kesenjangan pendanaan pemerintahan antar daerah. Dana perimbangan terdiri atas Dana Bagi Hasil (DBH), Dana Alokasi Umum (DAU dan Dana Alokasi Khusus (DAK). Komponen Dana Perimbangan merupakan sumber penerimaan daerah yang sangat penting dalam pelaksanaan desentralisasi dan dalam kebijakan fiskal, dana perimbangan merupakan inti dari desentralisasi fiskal (Putra, 2018,.217).

Indikator pertumbuhan ekonomi suatu daerah dalam kurun waktu tertentu adalah Produk Domestik Regional Bruto (PDRB). Menurut Sukirno (2011,.423), merupakan perkembangan fisikal produksi barang dan jasa yang berlaku di suatu daerah, seperti pertambahan dan jumlah produksi barang industri, perkembangan infrastruktur, pertambahan jumlah sekolah, pertambahan produksi sektor jasa dan pertambahan produksi barang modal. Menurut Putra $(2018,220)$ berdasarkan hasil estimasi antara desentralisasi fiskal terhadap pertumbuhan ekonomi di provinsi di Indonesia, menunjukkan bahwa desentralisasi berpengaruh positif terhadap pertumbuhan ekonomi tetapi secara stattistik tidak signifikan. Ini menunjukkan bahwa dengan desentralisasi fiskal, maka akan semakin meningkatkan pertumbuhan ekonomi daerah. Laju pertumbuhan PAD Provinsi Sumatera Selatan,selama periode 2014-2018, rata-rata sebesar 15,2\%. Namun apabila dilihat laju pertumbuhan per tahun, terdapat pertumbuhan negatif yaitu 46,6\% dan 5,60\%, masing-masing terjadi pada tahun 2014 dan 2016. Laju pertumbuhan PAD tertinggi dicapai pada tahun 2015, yaitu sebesar 73,68\%.Selanjutnya, laju pertumbuhan Dana Perimbangan, dalam periode yang sama, rata-rata sebesar 10,36\%. Laju pertumbuhan negatif terjadi di tahun 2014, 2016 dan 2018, masing-masing sebesar 2,92\%, 1,23\% dan $10,93 \%$.. 
Laju pertumbuhan PDRB sebagai indikator pertumbuhan ekonomi, selama periode 2014-2018 adalah sebesar 5,16\%. Laju pertumbuhan PDRB ini setiap tahun mengalami peringkatan. Hubungan antara pertumbuhan PAD, Dana perimbangan dan PDRB Provinsi Sumatera Selatan terdapat pada Gambar 1 berikut ini :

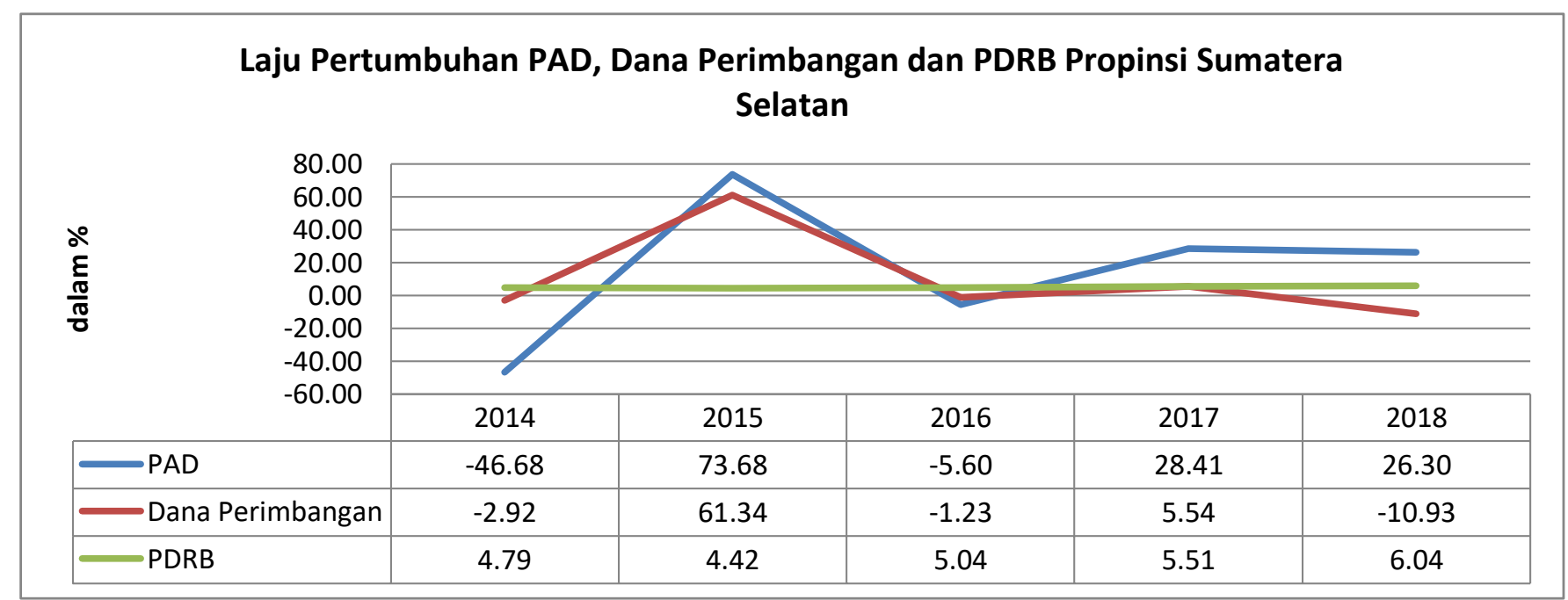

Sumber : bi.go.id (diolah)

\section{Gambar 1.}

Laju Pertumbuhan PAD, Dana Perimbangan dan PDRB Provinsi Sumatera Selatan 2014-2018

Penelitian ini berbeda dengan penelitian yang telah dilakukan sebelumnya, yaitu dalam variabel yang digunakan. Dalam penelitian ini variabel yang digunakan adalah Pendapatan Asli Daerah, Dana Perimbangan dan Pertumbuhan Ekonomi. Variabel penelitian yang dilakukan oleh Manek,et,al (2016) adalah Pendapatan Asli Daerah, Dana Perimbangan, Pertumbuhan Ekonomi dan Kemiskinan. Penelitian dari Wiraswasta, et.al (2018) menggunakan variabel Pendapatan Asli Daerah, Dana Perimbangan, Pertumbuhan Ekonomi dan Belanja Modal..

Selanjutnya, variabel yang digunakan dalam penelitian Siswiyanti (2015), adalah Pendapatan Asli Daerah, Dana Alokasi Umum, Dana Alokasi Khusus dan Pertumbuhan Ekonomi dengan Belanja Modal sebagai variabel intervening. Dalam penelitian yang dilakukan Nisa (2017), variabel yang digunakan adalah Pendapatan Asli Daerah, Dana Alokasi Umum, Bagi Hasil Pajak dan Pertumbuhan Ekonomi.Variabel yang digunakan dalam penelitian Priambodo (2015) adalah Pendapatan Asli Daerah, Belanja Modal, Tenaga Kerja dan Pertumbuhan Ekonomi.

\section{METODE PENELITIAN}

Penelitian ini bertujuan untuk menguji secara empiris pengaruh 2 (dua) variabel bebas (independent) yaitu PAD dan Dana Perimbangan terhadap 1 (satu) variabel tidak bebas (dependent) yaitu pertumbuhan ekonomi (PDRB). Oleh karena itu jenis penelitian yang digunakan adalah penelitian hipotesis atau hypothesis testing research. Jenis data yang digunakan adalah data sekunder, yaitu merupakan data kuantitaif yang meliputi data pertumbuhan PAD, Dana Perimbangan dan pertumbuhan PDRB. Data tersebut diperoleh dari BPS Provinsi Sumatera Selatan berupa Sumatera Selatan Dalam Angka dan web resmi Bank Indonesia dalam bentuk Kajian Ekonomi dan Keuangan Provinsi Sumatera Selatan.

Metode analisis yang digunakan ada 2 pendekatan yaitu analisis statistik deskriptif dan analisis regresi linear berganda (multiple regression), dengan persamaan sebagai berikut :

$\mathrm{Y}=\beta_{0}+\beta_{1} \mathrm{X}_{1}+\beta_{2} \mathrm{X}_{2} \quad$ dimana $\mathrm{Y}=$ Pertumbuhan Ekonomi; $\mathrm{X}_{1}=\mathrm{PAD} ; \mathrm{X}_{2}=$ Dana Perimbangan

Pengujian hipotesis dilakukan dengan menggunakan alat analisis :

1. Uji Signifikan Simultan (Uji Statitsik F) digunakan untuk mengetahui pengaruh PAD dan Dana Perimbangan secara bersama-sama (simultan) terhadap PDRB 
2. Uji Siginifikan Parameter Individual (Uji Statistik t) digunakan untuk menguji pengaruh PAD terhadap PDRB dan pengaruh Dana Perimbangan terhadap PDRB

3. Uji Koefisien Determinasi untuk menentukan proporsi atau persentase total PDRB yang diterangkan oleh PAD dan Dana Perimbangan

HASIL DAN PEMBAHASAN

Hasil Uji Statitsik F simultan dalam analisis regresi berganda, dapat dijelaskan melalui tabel output ANOVA, berikut ini :

Tabel 1

ANOVA

\begin{tabular}{|c|c|c|c|c|c|c|}
\hline & Model & Sum of Squares & $\mathrm{df}$ & Mean Square & $\mathrm{F}$ & Sig. \\
\hline \multirow[t]{3}{*}{1} & Regression & $1,270 \mathrm{E}+28$ & 2 & \multirow{3}{*}{$\begin{array}{l}6,349 \mathrm{E}+27 \\
1,052 \mathrm{E}+26\end{array}$} & \multirow[t]{3}{*}{60,373} & \multirow[t]{3}{*}{, $004^{\mathrm{b}}$} \\
\hline & Residual & $3,155 \mathrm{E}+26$ & 3 & & & \\
\hline & Total & $1,301 \mathrm{E}+28$ & 5 & & & \\
\hline
\end{tabular}

Sumber: data diolah

Untuk melakukan uji hipotesis dalam uji F ada 2 (dua) acuan yang dapat digunakan yaitu :

1. Nilai siginifikansi (sig)

Nilai sig adalah sebesar 0.004. Karena sig 0,004 < 0,005, maka hipotesis diterima. Artinya PAD dan Dana Perimbangan berpengaruh secara simultan terhadap PDRB.

2. Perbandingan Nilai F hitung dan F tabel

Berdasarkan tabel 1, nilai F hitung sebesar 60,373. Karena nilai F hitung 60,373 < F tabel 6,94, maka hipotesis diterima. Artinya PAD dan Dana Perimbangan berpengaruh secara simultan terhadap PDRB.

Hasil ini tidak sesuai dengan penelitian yang telah dilakukan oleh Lisa,et.al (2017) bahwa PAD dan Dana Perimbangan berpengaruh negatif terhadap pertumbuhan ekonomi melalui Belanja Langsung dan berpengaruh positif dan siginifikan terhadap pertumbuhan ekonomi melalui Belanja Tidak Langsung. Demikian juga dengan hasil penelitian yang dilakukan oleh Paat, et.al(2019) bahwa PAD dan Dana Perimbangan mempunyai pengaruh yang tidak siginfikan terhadap pertumbuhan ekonomi.

Hasil Uji Statitsik t parsial dalam analisis regresi berganda, dapat dijelaskan melalui tabel output Coefficients, berikut ini :

Tabel 2

Coefficients $^{\mathbf{a}}$

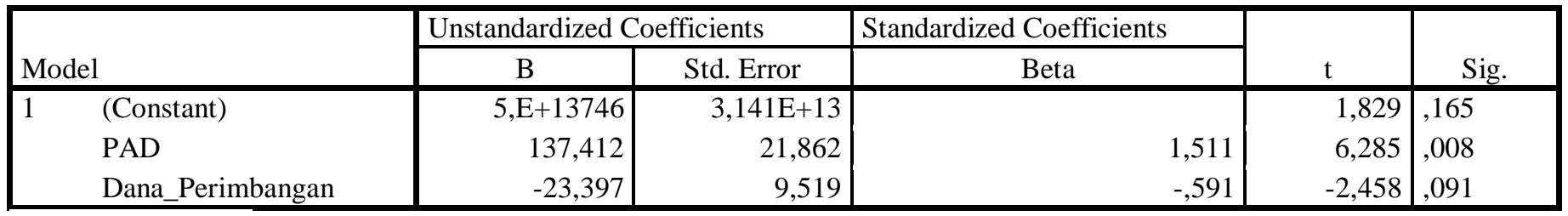

Sumber: data olahan

Untuk melakukan uji hipotesis dalam uji F ada 2 (dua) acuan yang dapat digunakan yaitu :

1. Nilai Siginifikansi

Berdasarkan Tabel 2, diperoleh nilai sig variabel PAD sebesar 0,008. Karena nilai sig 0,008< probabilitas 0,05 , maka $\mathrm{H}_{1}$ diterima . Artinya ada pengaruh PAD terhadap PDRB. Nilai sig Dana Perimbangan sebesar 0.091. Karena nilai sig 0,091>0,05, maka $\mathrm{H}_{2}$ ditolak . Artinya tidak ada pengaruh Dana Perimbangan terhadap PDRB.

2. Perbandingan Nilai thitung dan $t$ tabel

Nilai t hitung untuk variabel PAD dari tabel diatas adalah sebesar 6,285. Karena nilai t hitung variabel PAD 6,285 > 3,182, maka $\mathrm{H}_{1}$ diterima . Artinya ada pengaruh PAD terhadap PDRB. Nilai t hitung untuk variaabel Dana Perimbangan adalah sebesar -2,458. Karena nilai t hitung variabel Dana Perimbangan $2,458<3,182$ maka $\mathrm{H}_{2}$ ditolak. Artinya tidak ada pengaruh Dana Perimbangan terhadap PDRB. 
Hasil perhitungan ini sesuai dengan penelitian yang dilakukan oleh Manek,et.al(2016) yang menyatakan bahwa PAD berpengaruh siginifikan postif terhadap pertumbuhan ekonomi, dan Dana Perimbangan berpengaruh siginifikan negatif terhadap pertumbuhan ekonomi. Hasil penelitian dari Putri (2015) juga menyatakan bahwa variabel PAD berpengaruh signifikan terhadap pertumbuhan ekonomi.. Sementara untuk variabel Dana Perimbangan, tidak sesuai dengan hasil penelitian yang dilakukan oleh Chandra (2017), yang menyatakan bahwa Dana Perimbangan secara nyata berdampak baik terhadap pertumbuhan ekonomi, dengan hasil estimasi apabila Dana Perimbangan meningkat 1\%, maka pertumbuhan ekonomi di Propinsi Jambi akan meningkat sebesar 2,8594\%.

\section{Uji Koefisien Determinasi}

Koefisien determinasi atau R Square merupakan kontribusi pengaruh yang diberikan vaiabel bebas (X) terhadap variabel terikat (Y). Nilai koefisien determinasi ini mempunyai makna apabila hasil uji $\mathrm{F}$ dalam analisis regresi berganda terdapat pengaruh yang simultan.. Berdasarkan hasil perhitungan dari tabel 1. ANOVA, telah diperoleh hasil bahwa PAD dan Dana Perimbangan berpengaruh secara simultan terhadap PDRB,s maka nilai koefisien determinasi dapat dipergunakan. Hasil analisis liner berganda yang digunakan adalah Model Summary, sebagai berikut :

Tabel 3

Model Summary

\begin{tabular}{|l|l|l|l|l|}
\hline Model & R & R Square & Adjusted R Square & Std. Error of the Estimate \\
\hline 1 &, $988^{\mathrm{a}}$ &, 976 &, 960 & $1,02546 \mathrm{E}+13$ \\
\hline
\end{tabular}

Sumber: data olahan

Tabel 3 diatas diperoleh R Square sebesar 0.976 atau 97,6\% mengandung arti bahwa PAD dan Dana Perimbangan secara simultan berpengaruh terhadap PDRB sebesar 97,6\%. Sedangkan selebihnya, yaitu 4\% dipengaruhi oleh variabel lain diluar persamaan regresi. Menurut Undang-undang No.32 Tahun 2004 pasal 157 dan Undang-undang No.33 Tahun 2004 pasal 6 tentang Perimbangan Keuangan Pusat dan Daerah, bahwa sumber pendapatan daerah selain Pad dan Dana Perimbangan adalah Lain-lain Pendapatan yang Sah.

\section{Analisis Regresi Linear Berganda}

Persamaan regresi bertujuan untuk melihat ada tidaknya pengaruh variabel PAD dan Dana Perimbangan secara parsial terhadap variabel pertumbuhan ekonomi. Persamaan regresi dari hasil penelitian ini adalah : $\mathrm{Y}=5, \mathrm{E}+13746+137,412 \mathrm{X}_{1}-23,397 \mathrm{X}_{2}$

Persamaan tersebut menjelaskan bahwa bila terjadi kenaikan PAD sebesar $1 \%$, maka akan meningkatkan pertumbuhan ekonomi sebesar $137,412 \%$, sementara variabel Dana Perimbangan disaumsikan tetap. Sedangkan untuk variabel Dana Perimbangan bila terjadi kenaikan sebesar 1\% maka akan menurunkan pertumbuhan ekonomi sebesar 23,397\%, dengan asumsu variabel PAD diasumsikan tetap

Dana Perimbangan terdiri dari Dana Bagi Hasil (DBH), Dana Alokasi Umum (DAU) dan Dana Alokasi Khusus (DAK). Hasil penelitian yang dilakukan oleh Kusumawati,et.al (2018), menjelaskan bahwa DBH dan DAU berpengaruh negatif terhadap pertumbuhan ekonomi. Hasil penelitian yang dilakukan oleh Nurkhayat,et.al(2018), menunjukkan bahwa DHB berpengaruh negatif terhadap pertumbuhan ekonomi. Pengaruh negatif DBH terhadap pertumbuhan ekonomi dimungkinkan jika tambahan DBH diperoleh melalui proses penarikan pajak yang terlalu tinggi yang dapat menhambat aktivitas ekonomi di suatu daerah. Berdasarkan hasil penelitian yang dilakukan Eliza,et.al (2014), menunjukkan bahwa peningkatan variabel DAK akan menurunkan pertumbuhan ekonomi, dengan asumsi DBH dan DAU tetap.

\section{SIMPULAN}

Kesimpulan yang diperoleh dari hasil penelitian ini bahwa PAD dan Dana Perimbangan secara simultan berpengaruh positif dan siginifikan terhadap pertumbuhan ekonomi provinsi Sumatera Selatan. Hal ini menunjukkan bahwa, apabila terjasi peningkatann PAD dan Dana Perimbangan secara bersama-sasma, akan meningkatkan pertumbuhan ekonomi. Secara parsial, Pendapatan Asli Daerah (PAD) berpengaruh siginifikan dan positif terhadap pertumbuhan ekonomi provinsi Sumatera Selatan. Hasil ini menunjukkan 
bahwa semakin tinggi PAD maka semakin tinggi pertumbuhan ekonomi. Sedangkan Dana Perimbangan berpengaruh negatif terhadap pertumbuhan ekonomi, artinya terjadinya pertambahan Dana Perimbangan menyebabkan penurunan pada pertumbuhan ekonomi.

\section{DAFTAR PUSTAKA}

Chandra,Dodi.,Hidayat,Syurya.,Rosmeli.(2017). Dampak Dana Perimbangan Terhadap Pertumbuhan Ekonomi Dan Ketimpangan Antar Daerah Di Provinsi Jambi. Jurnal Paradigma Ekonomika, 12(2),6776. Diakses dari https://online-journal.unja.ac.id

Chrisanty Paat,Dewi.,AM Koleangan, Rosalina ., Adolf Rumeke, Vikie.(2017). Pengaruh Pendapatan Asli Daerah (PAD) dan Dana Perimbangan terhadap Pertumbuhan Ekonomi Serta Dampaknya Terhadap Kemiskinan di Kota Bitung. Jurnal Pembanguan dan Keuangan Daerah, 19(1), 1-10. Diakses dari Error! Hyperlink reference not valid.Eliza,Zulfa., Muhammad, Said.,Nasir, Muhammad. (2014).Analisis Pengaruh Dana Perimbangan terhadap Pertumbuhan PDRB di Provinsi Aceh.Jurnal Ilmu Ekonomi Pascasarjana Universitas Syiah Kuala, 2(1), 44-54. Diakses dari https://jurnal.unsyiah.ac.id

Kusumawati, Lily.,Wiksuana,IGB. (2018). Pengaruh Pendapatan Asli Daerah terhadap Pertumbuhan Ekonomi di Wilayah Sarbagita Provinsi Bali. E-jurnal Manajemen Unud,7(5), 2592-2620. Diakses dari https://doi.org/10.24843/EJUNUD.208.v7.i05.p12

Lisa,Yulianus.,Priyagus. (2017). Pengaruh pendapatan asli daerah dan dana perimbangan terhadap belanja langsung dan belanja tidak langsung serta pertumbuhan ekonomi di Indonesia. Forum Ekonomi, 19(2), 162-173. Diakses dari http://journal.feb.unmul.ac.id/index.php/FORUMEKONOMI.

Manek, Marianus.,Badrudin,Rudy.(2016). Pengaruh Pendapatan Asli Daerah Dan Dana Perimbangan Terhadap Pertumbuhan Ekonomi Dan Kemiskinan Di Provinsi Nusa Tenggara Timur. Jurnal Telaah Bisnis, 17(2),81-98. Diakses dari http://journal.stimykpn.ac.id/index.php/tb

Nurkhayat,Ahmad.,Firdaus, Muhammad., Mulatsih,Sri.(2018). Strategi Optimalisasi Dana Perimbangan di Indonesia. Jurnal Manajemen Pembangunan Daerah, 10(1),2018, 35-47. Diakses dari https://journal.ipb.ac.id

Priambodo,Agung.(2015). Analisis Pengaruh Pendapatan Asli Daerah, Belanja Modal, Tenaga Kerja Terhadap Pertumbuhan Ekonomi. Jurnal Ekonomi Pembangunan, 4(1), 1-9. Diakses dari http://journal.unnes.ac.id/sju/index-php/edaj

Putra, Windhu. (2018). Perekonomian Indonesia : Penerapan Beberapa Teori Ekonomi Pembangunan di Indonesia. Penerbit Raja Grafindo Persada, Jakarta

Putri, Zuwesty Eka.(2015). Analisis Pengaruh Pendapatan Asli Daerah (Pad), Dana Alokasi Umum (Dau) Dan Inflasi Terhadap Pertumbuhan Ekonomi Di Kabupaten/Kota Provinsi Jawa Tengah. Jurnal Bisnis dan Manajemen, 5(2),173-186. Diakses dari http://journal.uinjkt.ac.id/index.php/esensi/issue/view/337

Siswiyanti, Pungki.(2015). Pengaruh Pad, Dau, Dak Terhadap Pertumbuhan Ekonomi Dengan Belanja Modal Sebagai Variabel Intervening. Jurnal Akrual,7(1), 1-17. Diakses dari http://journal.unesa.ac.id/php.index/aj

Sukirno, Sadono. (2011). Makro Ekonomi : Teori Pengantar. Edisi ketiga. Penerbit Raja Grafindo Persada, Jakarta.

Supranto,J.,Abdullah,Syahfirin.(2017). Pengantar Statistik untuk Berbagai Bidang Ilmu. Penerbit Raja Grafindo Persada, Jakarta.

Wiraswasta, Fani.,Pudjiharjo,M.,Adis,Putu Mahardika. (2018). Pengaruh Dana Perimbangan Dan Pendapatan Asli Daerah (Pad) Terhadap Pertumbuhan Ekonomi Melalui Belanja Modal Di Kota Dalam Wilayah Jawa Timur (Tahun 2009-2014).Jurnal Bisnis dan Manajemen,5(2),17-180. 